\title{
Minimally Invasive Surgery in Mild-to-Moderate Glaucoma Patients in Italy: Is It Time to Change?
}

This article was published in the following Dove Press journal: Clinical Ophthalmology

\author{
Ciro Costagliola (1D \\ Mario Sbordone ${ }^{2}$ \\ Stefano Gandolfi ${ }^{3}$ \\ Luca Cesari ${ }^{4}$ \\ Gianluca Furneri $\mathbb{1 D}^{5}$ \\ Antonio Maria Fea (iD) ${ }^{6}$ \\ 'Department of Medicine \& Health \\ Sciences "V. Tiberio", University of \\ Molise, Campobasso, Italy; \\ ${ }^{2}$ Ophthalmology Unit, Santa Maria Delle \\ Grazie Hospital, Pozzuoli, Naples, Italy; \\ ${ }^{3}$ Ophthalmology Unit, Department of \\ Biological, Biotechnological and \\ Translational Sciences, University of \\ Parma, Parma, Italy; ${ }^{4} \mathrm{UOC}$ \\ Ophthalmology - Area 5, Ascoli Piceno, \\ San Benedetto del Tronto, Italy; ${ }^{5}$ EBMA \\ Consulting SRL, Melegnano, Milan, Italy; \\ ${ }^{6}$ Department of Surgical Sciences, \\ University of Turin, Turin, Italy
}

\begin{abstract}
Medical therapy is the first treatment choice for most patients with glaucoma; however, in a relevant proportion of patients, intraocular pressure (IOP) reduction is achieved with multi-therapy and/or high therapeutic doses. Conventional surgery is the standard alternative to medical therapy when this is not effective or not tolerated. Recently, selective laser trabeculoplasty (SLT) has been advocated as first-line therapy, and "minimally invasive glaucoma surgery" (MIGS) has been developed as safer and less traumatic surgical intervention for patients with glaucoma. Schlemm's canal surgery has emerged as one of the approaches with the most favorable risk-benefit profile for glaucoma patients in need of cataract surgery. However, despite the promising results, use of MIGS in Italy has been extremely low. We aimed to investigate the reasons of the lower-than-expected use of Schlemm's canal-based MIGS devices in Italy, share our perspective on their potential place in therapy, and give practical suggestions to improve the management of glaucoma patients.
\end{abstract}

Keywords: minimally invasive surgery, glaucoma, IOP reduction, trabecular bypass, cataract surgery

\section{Introduction}

Glaucoma is an optic neuropathy characterized by the progressive degeneration of the retinal ganglion cells, with consequent visual field loss, which slowly leads to blindness. ${ }^{1}$

Glaucoma represents one of the major health problems, being the second cause of blindness worldwide, and its prevalence is still growing very quickly (about 80 million people affected). ${ }^{2}$ In Italy, recent estimates show that about 550 thousand subjects have a confirmed diagnosis of glaucoma; this corresponds to about $2 \%$ prevalence in population aged $\geq 40$ years. ${ }^{3}$ Furthermore, glaucoma is a burdensome condition that can dramatically affect individuals' quality of life (QoL): irreversible visual impairment and potential blindness caused by glaucoma have an extremely negative impact on patients' physical and mental health. ${ }^{4}$

In primary open-angle glaucoma (POAG) patients, outflow obstruction at the level of the trabecular meshwork and Schlemm's canal is likely the main cause of high intraocular pressure (IOP). Many patients with POAG also have a concomitant cataract: this association is reported in the published literature, and it was demonstrated that patients with glaucoma are at higher risk of developing cataract. ${ }^{5-8}$ Both cataract and glaucoma are age-related diseases, and they are likely to present concomitantly in elderly people. ${ }^{9-18}$ Several studies have demonstrated that cataract extraction alone in
Correspondence: Gianluca Furneri EBMA Consulting SRL, Via per Carpiano, 2 - 20077, Melegnano, MI Italy Email gianluca.furneri@ebmaconsulting.com 
glaucoma patients can reduce IOP. ${ }^{19-22}$ However, there is still an important unmet need in these patients. ${ }^{23}$ Optimal target IOP will be obtained with medical treatment, glaucoma surgery, or both. In the last decade, minimally invasive glaucoma surgery (MIGS) has been developed as safer and less traumatic surgical intervention for patients with glaucoma versus incisional surgery. ${ }^{24}$ In Italy, few devices are currently marketed (GATT, ABiC, Kahook, iStent inject). iStent inject ${ }^{\circledR}$ (Glaukos Corporation, San Clemente, CA, US, hereafter "second-generation trabecular micro-bypass stent" - TBS) has emerged as a safe option among MIGS device, as it does not require trabecular meshwork removal. ${ }^{25-28}$

In Italy, the adoption rate of these emerging treatments (selective laser trabeculoplasty - SLT, MIGS) is still low compared with other European countries and the US. This can be explained by two main reasons: i) only a few specialized centers perform SLT and MIGS regularly, whereas most hospitals stick to the traditional treatment approach in uncontrolled, advanced, or severe cases; ii) treatment success rate with the first methods introduced in medical practice (Trabectome ${ }^{\circledR}$ and iStent ${ }^{\circledR}$ ) has been modest.

Despite the limited offer of new therapeutic options, the treatment demand in Italy is high and constantly increasing. In fact, about 550,000 patients undergo cataract extraction every year. Assuming that $5 \%-10 \%$ of these patients have (or will develop) glaucoma, ${ }^{29}$ there would be a maximum of about 50,000 patients/year in need of a combined intervention of cataract extraction and glaucoma management.
In this paper we aim to: i) analyze the reasons of the lower-than-expected use of glaucoma emerging treatments; ii) give practical suggestions to improve management of glaucoma patients and address the current unmet needs in this area; iii) share our perspective on the potential place in therapy of MIGS, and second-generation TBS specifically, in glaucoma.

\section{Key-Decision Treatment Criteria in Glaucoma}

The ultimate goal of glaucoma treatment is to minimize the optic nerve damage and to safeguard the residual visual field/ capacity of patients. This can be achieved through sustained IOP reduction. ${ }^{30,31}$ The European Glaucoma Society (ESG) Guidelines (Year 2017 ${ }^{32}$ ) state that "there is not enough evidence to support any particular algorithm to set the target IOP'. However, in clinical practice, identification of absolute IOP target reduction $(<21 \mathrm{mmHg},<18 \mathrm{mmHg}$, etc.) and relative (vs baseline) IOP target reduction $(\geq 20 \%, \geq 30 \%$, etc.) should depend on a multifactorial assessment of the patient. Figure 1 illustrates the main criteria driving the decision on IOP target level:

\section{Rate of Progression}

Optimal management of glaucoma implies that patients would be monitored and staged regularly with both functional tests (visual field; staging classification based on Hodapp, Parish and Anderson; H-P-A) and structural

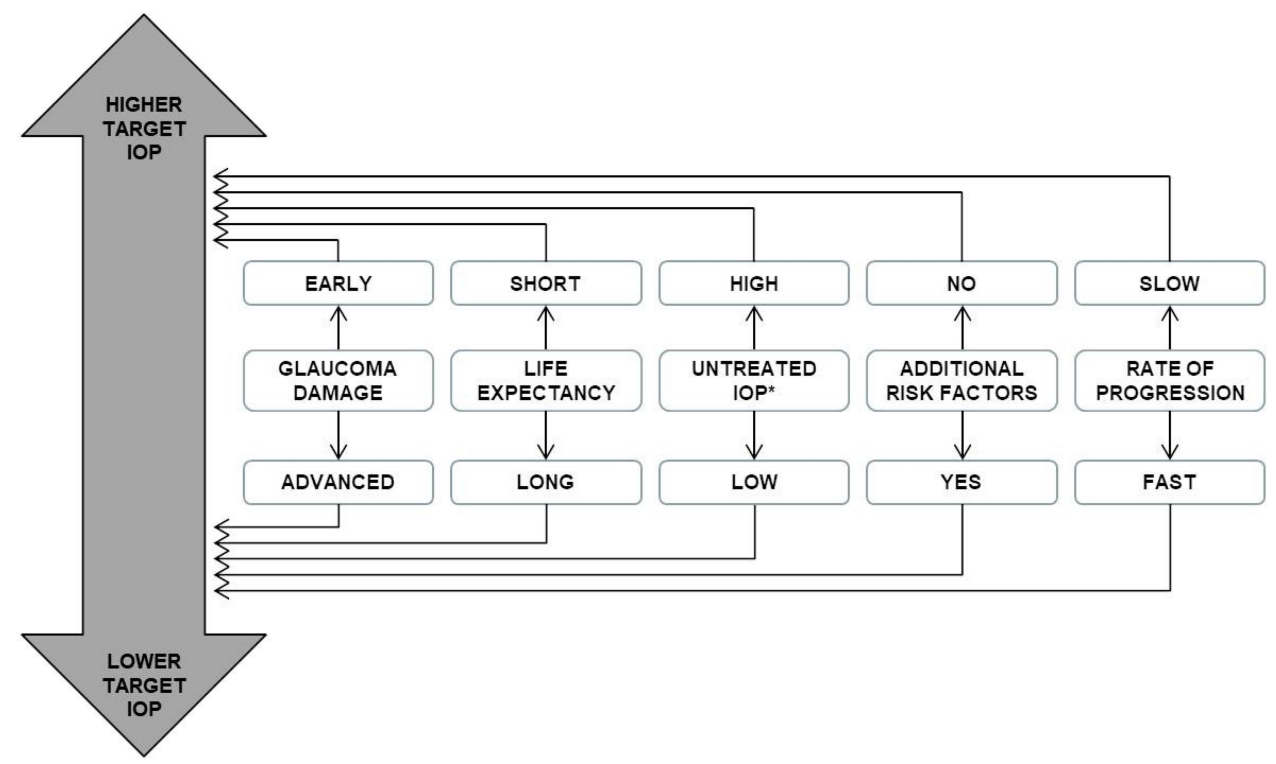

Figure I Main criteria for setting the target $1 \mathrm{OP}^{\circ} .{ }^{\circ}$ The above factors need to be considered as a whole in deciding the individual target pressure required. ${ }^{*}$ Consider central corneal thickness.

Abbreviation: IOP, intraocular pressure. 
tests. $^{33}$ This approach would help ophthalmologists to accurately assess the disease progression rate, and to select the more appropriate treatment approach, with filtering surgery being preferred over medical therapy and/ or minimally invasive approaches for highly progressing patients.

\section{Glaucoma Damage}

The more glaucoma is advanced, the higher is the need to target low IOP. ${ }^{32,34,35}$ Therefore, patients with significant glaucomatous damage require a more resolutive intervention to ensure that IOP would be significantly reduced and that residual visual field maintained.

\section{Age/Life Expectancy}

Likely, patients with early-onset are likely to manifest with glaucoma. ${ }^{34}$ In these cases, early intervention with effective, surgical treatment, is recommended to preserve visual functionality and avoid early visual impairment. ${ }^{36,37}$ Instead, for older patients, more conservative approach based on treatments with a minor alteration of the eye anatomy is preferred.

\section{Comorbidities and Risk Factors}

The presence of concomitant diseases increases with patients' age. In older patients with relevant comorbidities, the traditional surgical approach might be contraindicated or have a questionable risk-benefit ratio. In the latter case, the decision to perform surgery must be evaluated carefully, and other alternatives with a higher level of safety should be considered/preferred. As mentioned earlier, patients with mild-to-moderate glaucoma and cataract undergoing phacoemulsification and artificial lens implantation might have a limited benefit in time. $^{38,39}$

\section{Untreated IOP}

Unless patients have early-onset and/or rapidly evolving disease, the common glaucoma treatment approach is to start with less invasive options and then switch to more invasive treatments, in case the disease is not adequately controlled. However, an interesting debate has arisen on how to rank therapeutic interventions by the level of invasiveness, ie, level of anatomical modification of the eye, induced by the treatment.

\section{Glaucoma Treatment Landscape: General Overview Established Treatments}

For many years, the traditional paradigm of glaucoma treatment has been exclusively based on medical therapy (the recommended option to treat patients with initial mild-tomoderate disease) and on filtering surgery to manage patients with more advanced and/or rapidly progressing forms.

\section{Medical Therapy}

Several randomized clinical trials and observational studies have confirmed that antiglaucoma drugs are effective in reducing IOP at different stages of the disease. ${ }^{31,40-42}$ Different classes of drugs (alpha2-agonists, beta-blockers, topical carbonic anhydrase inhibitors, cholinergics, prostaglandins/prostamides, Rho kinase inhibitors), can be used, either as monotherapy or in combination. The choice of optimal medical therapy depends on multiple factors, such as clinical presentation of the patient, risk-benefit ratio of the treatment, likelihood of adherence, impact on patient QoL. Overall, treatment guidelines recommend administration of the minimal amount of medication (try to avoid high dosage and multitherapy) to achieve the desired IOP therapeutic goal. $^{32,43}$ Though medical therapy is a key-asset for ophthalmologists and their patients, certain treatment issues have been significantly debated among ophthalmologists. For instance, the occurrence of side effects (eye inflammation, itching, sight disturbances) causes poor adherence, thus reducing therapeutic effectiveness. Additionally, administration of eye drops is not easy for patients and their caregivers; administration is often performed suboptimally, and/or patients forget to self-administer the drug. Several clinical studies have shown that persistence to glaucoma medical therapy (intended as the length of time during which the patient is taking the medication as prescribed) is short: many patients tend to interrupt treatment early. ${ }^{44,45}$ In addition, topical treatments can cause injury to the conjunctiva and as a result can cause reduction in the effectiveness of surgery. ${ }^{44,45}$

Finally, IOP control is often achieved with multiple topical glaucoma medications and high therapeutic doses. Consequently, the achievement of target IOP is obtained at the cost of damaging the cornea, as prolonged use of highdose medical therapy can modify the eye anatomy. ${ }^{46-48}$

\section{Glaucoma Filtering Surgery}

Conventional surgery has been the standard alternative to medical therapy and the mainstay of treatment for 
glaucoma patients: i) who have failed to have IOP controlled with less invasive options; ii) who are contraindicated to medical therapy; iii) for whom a lower target IOP must be achieved; iv) who have early-onset and/or rapidly progressing glaucoma. The primary goal of surgery is to reduce IOP and medication. ${ }^{32,43}$

Conventionally, incisional surgery is classified into two main categories: i) anterior filtering surgery, and ii) posterior filtering surgery. Trabeculectomy is by far the most common of (penetrating) anterior filtering technique and is extensively used in OAG. Robust clinical evidence has shown that trabeculectomy is an effective treatment to achieve sustained IOP reduction without medical therapy. ${ }^{49-51}$ However, as for any surgical approach, safety remains a concern. Despite technological advancements, there is a periprocedural and postprocedural "ineliminable" risk of adverse events, such as hemorrhage, endophthalmitis (filtering post-procedure incidence ranges from $0.12 \%$ to $8.33 \%$ ), ocular infections, hypotony, visual loss $(8.3 \%$ of patients showed loss of visual acuity after the first 3 months post-surgery), cataract development (the risk of requiring cataract surgery is reported as ranging between $20 \%$ and $52 \%$ up to 7 years postoperatively). ${ }^{52,53}$ Also, the impact on QoL is non-negligible, with patients reporting post-surgical pain, and overall reluctance or fear to undergo surgery. ${ }^{4,54}$ Other non-penetrating techniques have been used as alternatives to trabeculectomy to potentially reduce the burden of complications, but with less satisfactory IOP outcomes and other technical issues. ${ }^{55-58}$

Finally, posterior filtering surgery is used as a rescue option for those refractory patients who are still uncontrolled despite anterior filtering surgery \pm medical therapy, or in patients in whom anterior filtration is not possible or has a high risk of failure. ${ }^{59-62}$ The use of tube shunts has grown in recent years. However, despite clinical evidence has shown favorable outcomes associated with posterior filtering surgery, uncertainty remains on the risks of surgical complications. ${ }^{63,64}$ Many glaucoma specialists still consider posterior filtration as a second option..$^{65,66}$

\section{Emerging Treatments}

\section{Selective Laser Trabeculoplasty (SLT)}

The initial attempts to use laser therapy to reduce IOP in glaucoma patients initiated almost 50 years ago. However, SLT, the most common and perhaps the most advanced among laser therapy techniques, has emerged as an option for glaucoma patients as of the early $2000 \mathrm{~s} .{ }^{67}$ The efficacy and safety of SLT have been evaluated in several clinical trials and observational studies. ${ }^{68-78}$ With respect to SLT, the LiGHT study is an interesting observer-masked, randomized controlled trial that enrolled treatment-naïve patients with open angle glaucoma or ocular hypertension and no ocular comorbidities. ${ }^{79}$ This is the first trial of a directly comparing SLT and intraocular pressurelowering drops in terms of health-related quality of life, clinical, and cost-effectiveness outcomes in a pragmatic hospital setting, guided by a robust treatment escalation protocol to capture realistic clinical management while minimizing risk of bias. In this study, patients were allocated to initial SLT or to eye drop. At 36 months, $74.2 \%$ (95\% CI 69.3-78.6) of patients in the selective laser trabeculoplasty group required no drops to maintain intraocular pressure at target. ${ }^{79}$ Overall, evidence shows that SLT reduces IOP levels and IOP fluctuation in patients with POAG and ocular hypertension (OHT) ${ }^{74,79,80}$ However, the effect of trabeculoplasty may be temporary. Nevertheless, SLT can be repeated, as it causes minimal damage to the trabecular meshwork.

With the current data, it is hard to compare the efficacy of SLT vs other glaucoma therapies. Recent meta-analyses of SLT vs medical therapy ${ }^{81,82}$ suggested that SLT would be as effective as medication. However, some methodological limitations of these analyses, combined with the lack of longterm efficacy data, suggest caution to avoid drawing erroneous conclusions, as evidence vs surgical therapy is still anecdotical. An analysis conducted in 2017 by Fea et al, ${ }^{83}$ which compared SLT vs MIGS, concluded that the two options achieved the same level of IOP reduction, but MIGS substantially reduced the use of concomitant medical therapy ( $47 \%$ of patients were medication-free at 12 months in the MIGS group vs $4 \%$ in the SLT group).

In terms of safety, data confirm that risks associated with SLT are low: serious adverse events are rare, while most of the non-serious adverse events are temporary and manageable. ${ }^{71}$

\section{Minimally Invasive Glaucoma Surgery (MIGS)}

Minimally invasive glaucoma surgery (MIGS) has been increasingly used over the last $5-10$ years; today it is universally acknowledged by the ophthalmology community as a valuable treatment option for glaucoma patients. MIGS offers a safer, less invasive means of reducing IOP than traditional surgery, with a goal of concomitantly reducing utilization of topical agents. ${ }^{84,85}$ MIGSs are surgical procedures with an ab-interno approach, minimal trauma with minimal or no scleral dissection, minimal or no conjunctival 
manipulation, good safety profile, and rapid recovery. ${ }^{86,87}$ However, MIGS comprises a broad range of techniques that are significantly different to each other in terms of riskbenefit profile. A proposed classification of MIGS is shown in Table 1 and is based on approach (ab-interno vs abexterno) and anatomical site of the intervention. As a matter of fact, only Schlemm's canal devices strictly meet the definition of MIGS (ie, ab-interno; at the most, limited scleral dissection and conjunctival manipulation). Schlemm's canal devices preserve the anatomical integrity of the angle structures more than the other options and induce less anatomical alterations. ${ }^{88}$ Furthermore, quality and number of evidences on Schlemm's canal devices is largely superior to the rest of other devices defined as MIGS. For these reasons, the present article aims to focus of Schlemm's canal devices, as best representatives of the MIGS class.

Recent reviews and meta-analyses on MIGS were conducted with the aim of assessing the efficacy and safety of these techniques, comparatively vs both medical therapy and surgery. ${ }^{86,89}$ In these evaluations, authors conclude that MIGS surgery is effective in reducing IOP and the use of glaucoma drugs. Also, MIGS showed a good safety profile; IOP spikes were the most frequent complications and no cases of infection or best-corrected visual acuity (BCVA) loss due to glaucoma were reported. However, the same authors pointed out the relatively modest quality of the evidence, which comes predominantly from non-comparative trials (only 9 trials out of more than 3,000 studies were randomized controlled trials). Visualization of the outflow pathways would be helpful to drive the choice of the MIGS device..$^{90,91}$

Among MIGS, iStent (Glaukos Corporation, San Clemente, CA, US, hereafter "first-generation TBS"), and currently, second-generation TBS have emerged as excellent options to achieve sustained IOP reduction without the disadvantages of ocular hypotensive medications. The TBS devices are implanted with an ab-interno procedure, designed to optimize the natural physiologic outflow of aqueous humor. Beyond efficacy, the greatest advantage of these micro-sized devices is they do not preclude filtering surgery that could be required in the future. ${ }^{25,64}$

The second-generation TBS is a 2-stent system that creates 2 patent bypasses through the trabecular meshwork. In 2011, the second-generation TBS was registered in Europe. To date, several studies have shown the safety and efficacy of second generation TBS in sustainably reducing IOP and use of medications, either as a combined procedure with concomitant cataract, ${ }^{27,92-97}$ or as a stand-alone procedure (Table 2). ${ }^{26,98-100}$

\section{Ophthalmic Drug Delivery Systems}

Compared with standard medical therapy, drug delivery systems have the potential to improve patient adherence, reduce side effects, increase efficacy, and ultimately, preserve sight of glaucoma patients. ${ }^{101,102}$ Among these treatments, the injectable systems have produced good results in the recent past. Injectable systems are passive delivery systems, capable of delivering medications to the target tissues for an extended period. The injectable systems are typically implanted at the site of drug release through a minimally invasive procedure, usually in an outpatient setting and they use a polymer delivery vehicle to prolong delivery up to a few months in the surrounding tissue. Recently, Durysta ${ }^{\circledR}$ (bimatoprost implant $10 \mathrm{mcg}$ ), the first intracameral, biodegradable sustainedrelease implant, was approved by FDA to reduce IOP in patients with open-angle glaucoma (OAG) or ocular hypertension (OHT). ${ }^{103}$

Table I Classification of MIGS,

\begin{tabular}{|c|c|c|c|}
\hline & Trabecular & Suprachoroidal / Uveoscleral & Subconjunctival \\
\hline $\begin{array}{l}\text { Ab-interno } \\
\text { procedure }\end{array}$ & $\begin{array}{l}\text { - } \text { Trabectome }{ }^{\circledR} \text { (NeoMedix, Tustin, CA, US) } \\
\text { - } \text { First-generation TBS (Glaukos Corp., San } \\
\text { Clemente, CA, US) } \\
\text { - } \text { Second-generation TBS (Glaukos Corp., San } \\
\text { Clemente, CA, US) } \\
\text { - } \text { Hydrus }{ }^{\circledR} \text { (Ivantis Inc., Irvine, CA, US) } \\
\text { - Canaloplasty Stegmann Canal }{ }^{\circledR} \text { (Ophthalmos } \\
\text { GmbH, Schaffhausen, Switzerland) }\end{array}$ & $\begin{array}{l}\text { - } \text { Cypass }^{\circledR} \text { (Alcon, Fort Worth, TX, } \\
\text { US })^{\mathrm{a}} \\
\text { - }{\text { iStent Supra }{ }^{\circledR} \text { (Glaukos Corp., San }} \text { Clemente, CA, US) }{ }^{\mathrm{b}}\end{array}$ & $\begin{array}{l}\text { - } \text { Subconjunctival implant (Aquesys } \\
\text { Implant, Aliso Viejo, CA, US) } \\
\text { - XEN (Allergan, Dublin, Ireland) }\end{array}$ \\
\hline $\begin{array}{l}\text { Ab-externo } \\
\text { procedure }\end{array}$ & - & $\begin{array}{l}\text { - Suprachoroidal gold micro shunt } \\
\text { (SOLX Inc., Waltham, MA, US) }\end{array}$ & $\begin{array}{l}\text { - PreserFlo/InnFocus (Santen, } \\
\text { Osaka, Japan) }\end{array}$ \\
\hline
\end{tabular}

Notes: Data from these studies. ${ }^{84,85}$. ${ }^{a}$ No longer available. ${ }^{b}$ Not commercially available.

Abbreviations: CA, California; MA, Massachusetts; TBS, trabecular micro-bypass stent; US, United States. 
Table 2 Summary of First- and Second-Generation TBS Main Clinical Evidence (Sources Within the Table)

\begin{tabular}{|c|c|c|c|c|c|}
\hline Author (Year) & Objective & Trial Design & Comparators & Follow-Up & Findings \\
\hline $\begin{array}{l}\text { Samuelson } \\
(2011)^{20}\end{array}$ & $\begin{array}{l}\text { Assess the safety and } \\
\text { efficacy of the first- } \\
\text { generation TBS in } \\
\text { combination with } \\
\text { cataract surgery, in } \\
\text { subjects with mild to } \\
\text { moderate OAG. }\end{array}$ & $\begin{array}{l}\text { Prospective, } \\
\text { randomized, } \\
\text { open label trial. }\end{array}$ & $\begin{array}{l}\text { Cataract } \\
\text { surgery with } \\
\text { first-generation } \\
\text { TBS }(\mathrm{N}=\mathrm{III}) \\
\text { vs cataract } \\
\text { surgery only } \\
(\mathrm{N}=122) \text {. }\end{array}$ & $\begin{array}{l}12 \text { months } \\
\text { (primary } \\
\text { endpoint) and } 24 \\
\text { months }\end{array}$ & $\begin{array}{l}\text { - At I year, significantly lower IOP (vs baseline) in } \\
\text { both treatment groups. } \\
\text { - Unmedicated IOP }<2 \text { I mmHg at I year in } 72 \% \text { of } \\
\text { first-generation TBS treated eyes, vs } 50 \% \text { of con- } \\
\text { trol eyes }(\mathrm{P}<0.00 \mathrm{I}) \text {. } \\
\text { - } \geq 20 \% \text { IOP reduction without medication in } 66 \% \\
\text { of first-generation TBS treated eyes, vs } 48 \% \text { of } \\
\text { control eyes ( } \mathrm{P}=0.003 \text { ). } \\
\text { - Incidence of adverse events similar between } \\
\text { groups. }\end{array}$ \\
\hline Fea $(2014)^{26}$ & $\begin{array}{l}\text { Evaluate efficacy } \\
\text { of second-generation } \\
\text { TBS in OAG patients } \\
\text { not controlled on one } \\
\text { medication. }\end{array}$ & $\begin{array}{l}\text { Prospective, } \\
\text { randomized trial. }\end{array}$ & $\begin{array}{l}\text { Surgery with } \\
\text { two second- } \\
\text { generation TBS } \\
(\mathrm{N}=94) \text {, vs } \\
\text { medical } \\
\text { therapy } \\
(\mathrm{N}=98) \text { with } \\
\text { latanoprost/ } \\
\text { timolol. }\end{array}$ & 12 months & $\begin{array}{l}\text { - Reduction of } \geq 20 \% \text { in } 94.7 \% \text { of eyes with second- } \\
\text { generation TBS, and in } 91.8 \% \text { of eyes with medical } \\
\text { therapy, vs baseline unmedicated IOP. } \\
\text { - } 17.5 \% \text { between-group treatment difference in } \\
\text { favor of second-generation TBS ( } \mathrm{P}=0.02 \text { ) at the } \\
\geq 50 \% \text { level of IOP reduction. } \\
\text { - IOP } \leq 18 \mathrm{mmHg} \text { in } 92.6 \% \text { of eyes with second- } \\
\text { generation TBS vs } 89.8 \% \text { of eyes in with medical } \\
\text { therapy group. } \\
\text { - High safety profile with second-generation TBS. }\end{array}$ \\
\hline $\begin{array}{l}\text { Arriola-Villalobos } \\
(2016)^{27}\end{array}$ & $\begin{array}{l}\text { Evaluate long-term } \\
\text { efficacy and safety of } \\
\text { the second-generation } \\
\text { TBS + cataract surgery } \\
\text { in patients with } \\
\text { coexistent cataract and } \\
\text { OAG and OHT. }\end{array}$ & $\begin{array}{l}\text { Prospective, } \\
\text { uncontrolled, } \\
\text { nonrandomized, } \\
\text { interventional } \\
\text { case series study. }\end{array}$ & $\begin{array}{l}\text { Cataract } \\
\text { surgery }+ \\
\text { two second- } \\
\text { generation TBS } \\
\text { devices } \\
(\mathrm{N}=20) .\end{array}$ & $\begin{array}{l}47.4 \pm 18.46 \\
\text { months }\end{array}$ & $\begin{array}{l}\text { - IOP decrease of } 36.92 \%, 9.74 \pm 3.14 \mathrm{mmHg} \\
\text { ( } \mathrm{P}<0.00 \mathrm{I}) \text {, from baseline. } \\
\text { - Mean number of medications reduced from } 1.3 \\
\pm 0.66 \text { to } 0.75 \pm 0.79(\mathrm{P}=0.0 \mathrm{I} 7) \text {. } \\
\text { - } 45 \% \text { of patients medication-free by the end of } \\
\text { follow-up. } \\
\text { - No complications of surgery. }\end{array}$ \\
\hline $\begin{array}{l}\text { Lindstrom } \\
(2016)^{132}\end{array}$ & $\begin{array}{l}\text { Outcomes following } \\
\text { implantation of } \\
\text { two second-generation } \\
\text { TBSs in patients with } \\
\text { open-angle glaucoma } \\
\text { on one Medication:18- } \\
\text { month follow-up. }\end{array}$ & $\begin{array}{l}\text { Prospective, } \\
\text { single-arm, } \\
\text { open-label study. }\end{array}$ & $\begin{array}{l}\text { Second- } \\
\text { generation TBS } \\
\text { standalone } \\
\text { procedure } \\
(\mathrm{N}=57) .\end{array}$ & 18 months & $\begin{array}{l}\text { - Postoperative mean IOP: } 14.4 \mathrm{mmHg} \text { trough } 18 \\
\text { months. } \\
\text { - Mean IOP at month I8: I4.4 mmHg (4I\% reduction } \\
\text { from the mean pre-operative unmedicated IOP of } \\
24.4 \mathrm{mmHg} ; 27 \% \text { reduction from the mean pre- } \\
\text { operative medicated IOP of } 19.5 \mathrm{mmHg} \text { ). } \\
\text { - High safety profile with second-generation TBS. }\end{array}$ \\
\hline $\begin{array}{l}\text { Hengerer } \\
(2018){ }^{95}\end{array}$ & $\begin{array}{l}\text { Prospective, non- } \\
\text { randomized, 36-month } \\
\text { study of second- } \\
\text { generation TBS with } \\
\text { phacoemulsification in } \\
\text { eyes with various types } \\
\text { of glaucoma. }\end{array}$ & $\begin{array}{l}\text { Prospective, } \\
\text { non- } \\
\text { Randomized, } \\
\text { consecutive } \\
\text { cohort study. }\end{array}$ & $\begin{array}{l}\text { Two second- } \\
\text { generation } \\
\text { TBSs } \\
\text { implantation } \\
+ \text { cataract } \\
\text { surgery } \\
(\mathrm{N}=8 \mathrm{I})\end{array}$ & 36 months & $\begin{array}{l}\text { - Mean postoperative IOP reduction of } 37 \% \text { ( } 14.3 \\
\pm 1.7 \mathrm{mmHg} \text { versus } 22.6 \pm 6.2 \mathrm{mmHg} \text { preopera- } \\
\text { tively), at } 36 \text { months. } \\
\text { - Mean medication burden decrease of } 68 \% \text { ( } 0.8 \\
\pm 0.9 \text { versus } 2.5 \pm 1.1 \text { medications preoperatively), } \\
\text { at } 36 \text { months. } \\
\text { - IOP reduction of } \geq 20 \% \text { in } 78 \% \text { of eyes; } 100 \% \text { of } \\
\text { eyes reached IOP } \leq 18 \mathrm{mmHg} \text { and } 71 \% \text { reached } \\
\leq 15 \mathrm{mmHg} \text {. } \\
\text { - From } 3 \mathrm{through} 36 \text { months, stable mean IOP } \\
\text { ( } \leq 15.0 \mathrm{mmHg} \text { ) and stable mean number of med- } \\
\text { ications }(\leq 0.9) \text {. }\end{array}$ \\
\hline
\end{tabular}

(Continued) 
Table 2 (Continued).

\begin{tabular}{|c|c|c|c|c|c|}
\hline Author (Year) & Objective & Trial Design & Comparators & Follow-Up & Findings \\
\hline $\begin{array}{l}\text { Samuelson } \\
(2019)^{25}\end{array}$ & $\begin{array}{l}\text { Evaluate safety and } \\
\text { effectiveness } \\
\text { of second-generation } \\
\text { TBS in combination } \\
\text { with cataract surgery in } \\
\text { subjects with mild to } \\
\text { moderate POAG. }\end{array}$ & $\begin{array}{l}\text { Prospective, } \\
\text { randomized trial. }\end{array}$ & $\begin{array}{l}\text { Second- } \\
\text { generation TBS } \\
(\mathrm{N}=387) \text {, vs no } \\
\text { stent } \\
\text { implantation } \\
\text { (control group, } \\
\mathrm{N}=118 \text { ). }\end{array}$ & 24 months & $\begin{array}{l}\text { - Reduction of } \geq 20 \% \text { unmedicated DIOP in } 75.8 \% \\
\text { of second-generation TBS treated eyes, vs } 61.9 \% \\
\text { of control eyes ( } P=0.005) \text {. } \\
\text { - Greater mean reduction in unmedicated DIOP } \\
\text { from baseline in second-generation TBS treated } \\
\text { eyes }(7.0 \pm 4.0 \mathrm{mmHg} \text { ) than in control eyes }(5.4 \\
\pm 3.7 \mathrm{mmHg} ; \mathrm{P}<0.00 \mathrm{I}) \text {. } \\
\text { - } 84 \% \text { of second-generation TBS treated eyes and } \\
67 \% \text { of control eyes were not receiving ocular } \\
\text { hypotensive medication at } 23 \text { months. } \\
\text { - } 63.2 \% \text { of treatment eyes vs } 50.0 \% \text { of control eyes } \\
\text { month } 24 \text { medication-free DIOP } \leq 18 \mathrm{mmHg} \\
\text { (difference } 13.2 \% \text {; } \mathrm{P}<0.05 \text { ). } \\
\text { - Similar safety profile in the two groups. }\end{array}$ \\
\hline $\begin{array}{l}\text { Hengerer } \\
(2019)^{133}\end{array}$ & $\begin{array}{l}\text { Second-generation TBS } \\
\text { as standalone } \\
\text { treatment for } \\
\text { glaucoma: A 36-month } \\
\text { prospective study. }\end{array}$ & $\begin{array}{l}\text { Prospective, } \\
\text { non-randomized, } \\
\text { consecutive } \\
\text { cohort study. }\end{array}$ & $\begin{array}{l}\text { Two second- } \\
\text { generation TBS } \\
\text { implantations } \\
(\mathrm{N}=44) .\end{array}$ & 36 months & $\begin{array}{l}\text { - At } 36 \text { months postoperatively, mean IOP reduc- } \\
\text { tion of } 42 \% \text { to I } 4.6 \pm 2.0 \mathrm{mmHg} \text { ( } \mathrm{p}<0.000 \mathrm{I} \text { ) and } \\
87.9 \% \text { of eyes achieved an IOP reduction of } \geq 20 \% \\
\text { versus preoperatively. } \\
\text { - } 97 \% \text { of eyes reached IOP } \leq 18 \mathrm{mmHg} \text { (vs } 9.1 \% \\
\text { preoperatively; } p<0.000 \text { I). } \\
\text { - } 70.0 \% \text { of eyes reached IOP } \leq 15 \mathrm{mmHg} \text { (vs } 2.3 \% \\
\text { preoperatively; } p<0.000 \text { I). } \\
\text { - Mean medication burden decrease of } 82 \% \text { to } 0.55 \\
\pm 0.79 \text { ( } \mathrm{p}<0.000 \mathrm{I} \text { ), and } 61 \% \text { of eyes became } \\
\text { medication-free. } \\
\text { - Minimal adverse events and stable CDVA through } \\
36 \text { months postoperatively. }\end{array}$ \\
\hline $\begin{array}{l}\text { Clement } \\
(2019)^{134}\end{array}$ & $\begin{array}{l}\text { One-year outcomes } \\
\text { following implantation } \\
\text { of second-generation } \\
\text { TBS in conjunction } \\
\text { with cataract surgery } \\
\text { for various types of } \\
\text { glaucoma or ocular } \\
\text { hypertension: } \\
\text { multicenter, multi- } \\
\text { surgeon study. }\end{array}$ & $\begin{array}{l}\text { Retrospective } \\
\text { outcomes } \\
\text { assessments. }\end{array}$ & $\begin{array}{l}\text { Second- } \\
\text { generation TBS } \\
\text { implantation } \\
+ \text { cataract } \\
\text { surgery } \\
(\mathrm{N}=290) .\end{array}$ & 12 months & $\begin{array}{l}\text { - Mean Month } 12 \text { IOP reduction of } 23.2 \% \text { ( } 18.27 \\
\pm 5.4 \mathrm{I} \mathrm{mmHg} \text { preoperatively to } 14.04 \pm 2.98 \\
\mathrm{mmHg} \text { ). } \\
\text { - } 95.8 \% \text { of eyes achieving Month } 12 \text { IOP of } \leq 18 \\
\mathrm{mmHg} \text { vs } 60.6 \% \text { preoperatively. } \\
\text { - } \text { Mean number of medications at } 12 \text { months } \\
\text { decrease of } 71.5 \%(0.47 \pm 0.95 \text { vs } 1.65 \pm 1.28 \\
\text { preoperatively). } \\
\text { - } 76.4 \% \text { of eyes were on zero medications vs } 17.6 \% \\
\text { preoperatively (P<0.00I). } \\
\text { - } 14.5 \% \text { of eyes were on } \geq 2 \text { medications vs } 46.7 \% \\
\text { preoperatively ( } \mathrm{P}<0.00 \mathrm{I}) \text {. } \\
\text { - } 98.2 \% \text { of eyes maintained or reduced medications } \\
\text { vs their preoperative regimen. } \\
\text { - Favorable safety profile, no stent-related intrao- } \\
\text { perative complications, and limited postoperative } \\
\text { adverse events. }\end{array}$ \\
\hline
\end{tabular}

(Continued) 
Table 2 (Continued).

\begin{tabular}{|c|c|c|c|c|c|}
\hline Author (Year) & Objective & Trial Design & Comparators & Follow-Up & Findings \\
\hline $\begin{array}{l}\text { Fechtner } \\
(2019)^{135}\end{array}$ & $\begin{array}{l}\text { Five-year, prospective, } \\
\text { randomized, multi- } \\
\text { surgeon trial of two } \\
\text { TBSs vs Prostaglandin } \\
\text { for newly diagnosed } \\
\text { open-angle glaucoma. }\end{array}$ & $\begin{array}{l}\text { Prospective, } \\
\text { randomized, } \\
\text { controlled trial. }\end{array}$ & $\begin{array}{l}\text { Surgery with } \\
\text { two first- } \\
\text { generation TBS } \\
(\mathrm{N}=54) \text {, vs } \\
\text { medical } \\
\text { therapy } \\
(\mathrm{N}=47) \text { with } \\
\text { topical } \\
\text { travoprost. }\end{array}$ & 5 years & $\begin{array}{l}\text { - Five-year mean diurnal IOP was } 16.51 .2 \mathrm{mmHg} \text { in } \\
\text { stent eyes ( } 35.3 \% \text { reduced vs } 25.52 .5 \mathrm{mmHg} \\
\text { preoperatively; } \mathrm{P}<0.000 \mathrm{I} \text { ) and } 16.31 .9 \mathrm{mmHg} \text { in } \\
\text { travoprost eyes ( } 35.1 \% \text { reduced vs } 25.14 .6 \mathrm{mmHg} \\
\text { preoperatively; } \mathrm{P}<0.000 \mathrm{I}) \text {. } \\
\text { - Add-on medication was initiated in } 12 \text { stent eyes } \\
\text { ( } 22.2 \% \text { of the initial } 54 \text {-eyes) and } 18 \text { travoprost } \\
\text { eyes ( } 38.3 \% \text { of the initial } 47 \text {-eyes). } \\
\text { - } 17 \% \text { (6/35) of stent eyes and } 44 \% \text { ( } 14 / 32) \text { of } \\
\text { travoprost eyes needed add-on medication to } \\
\text { control IOP ( } \mathrm{P}=0.017) \text {. } \\
\text { - Treatment success was achieved in } 77 \% \text { ( } 27 / 35 \text { ) of } \\
\text { stent eyes and } 53 \% \text { (I7/32) of travoprost eyes } \\
\text { ( } \mathrm{P}=0.04 \text { ). } \\
\text { - Both groups exhibited excellent safety. }\end{array}$ \\
\hline
\end{tabular}

Abbreviations: CDVA, corrected distance visual acuity; DIOP, diurnal intraocular pressure; IOP, intraocular pressure; OAG, open-angle glaucoma; OHT, ocular hypertension; POAG, primary open-angle glaucoma; TBS, trabecular micro-bypass stent.

In a Phase 3 study, this system showed $\sim 30 \%$ IOP reduction in IOP from baseline over a 12-week primary efficacy period, meeting the predefined criteria for noninferiority to the study comparator (twice-daily topical timolol). ${ }^{104}$ Moreover, bimatoprost implant improved adherence and reduced treatment burden in glaucoma.

\section{Glaucoma Treatment Landscape: State of Art in Italy}

In Italy, healthcare is supplied for all Italian population and is delivered mainly by public providers, with some private or private-public entities. Italy's public healthcare system, called Servizio Sanitario Nazionale (SSN), is organized by the Ministry of Health and administered on a devolved regional basis. It is funded by the government through taxation, to provide universal coverage, largely free of charge; however, about $30 \%$ of the population usually subscribes additional private health insurance plans.

Ophthalmology departments are part of general hospitals in all the Italian provinces; however, it is not uncommon to find specialized ophthalmic hospitals. More than 7,000 Italian ophthalmologists are members of the Italian Ophthalmological Society (SOI - Società Italiana di Oftalmologia-); the total number of ophthalmologists is estimated to exceed $8,000 .^{105,106}$

Treatments that are covered by the public health system through small patient co-payment include tests, medications, surgeries during hospitalization, family doctor visits and medical assistance provided by paediatricians and other specialists, out-patient treatments, and dental treatments.

Conventional surgery, MIGS and SLT are predominantly performed in public hospital ophthalmology wards, but they can also be executed in private clinics (accredited with the public sector). The treatment and surgery of glaucoma and cataract are classified under the basic national health benefits package, which is supplied to the whole population, called LEA (Livelli Essenziali di Assistenza - Essential Levels of Assistance). Although MIGSs were introduced some time ago, there is still no available codification (or reimbursement structure) specifically designed for this type of procedure in Italy. At present, Italian surgeons who perform MIGS and SLT procedures code them under "other glaucoma interventions"; in turn, the reimbursement may be insufficient, making hospitals unwilling to adopt and support this type of surgery.

Today, thanks to the emerging technological innovations developed and optimized during the last decade, ophthalmologists have more options to individualize glaucoma treatment and offer their patients targeted solutions to control IOP and disease progression. However, we have not seen a significant change in the treatment paradigm yet in Italy, or at least we have not seen it on a broad scale. Figure 2 provides a schematization of the current treatment landscape in Italy, based on our current knowledge. In this figure, treatments are ranked by level of use, across the different glaucoma stages. 
In our opinion, four evident issues are emerging from this picture: i) despite the availability of new interventions, especially for mild-to-moderate glaucoma patients, medical therapy remains, de facto, the only treatment adopted in Italy; ii) medical therapy is largely applied to all glaucoma stages, and the expected trend of reduced use of drugs after surgical interventions, observed in clinical trials, is not so evident in real practice; iii) SLT and MIGS are used sporadically, their use is limited to a few specialized centers in Italy; iv) whereas SLT and MIGS are used, they are used quite late in the therapeutic sequence, in moderate to advanced glaucoma cases that have been exposed to medical therapy for a long time and are not controlled any longer.

These four issues can be merged in a single consideration reflecting the present landscape in Italy: the majority of Italian ophthalmologists adopt a rather conservative approach; this implies a slow shift towards a reduction of the use of medical therapy in favor of minimally invasive techniques, specifically the second-generation TBS, which has been demonstrated to safely and sustainably reduce IOP and medications.

Analyzing the reasons for this slow rate of adoption and implementing approach modifying actions would be of crucial importance for our medical community.

The first issue, perhaps the most important, is the biased opinion among ophthalmologists on the value of medical therapy. Despite there is no doubt that medical therapy remains a valuable option for glaucoma patients, it has been "overused" in clinical practice. Long-term IOP control with hypotensive drugs in monotherapy at "normal dose ranges" is achieved in a relatively small proportion of patients and for a limited amount of time. ${ }^{31,107}$ Consequently, most patients are likely to receive more than 2 therapies in the course of their treatment pathway. The chronic use of multiple drugs in OAG is a relevant clinical issue, which is often underestimated in clinical practice. First, this impacts patients' QoL and their compliance; second, it increases the risk of conjunctival inflammation, induces damage on the ocular surface and compromises the success rate of subsequent trabeculectomy. ${ }^{108-111}$ Therefore, in some patients, this prolonged exposure to medical therapy inappropriately postpones surgery. Unfortunately, the high burden of medication might not be optimized and therefore not the best choice for the patients, because glaucomatous damage would be irreversible, and because outcomes of surgery would be negatively affected by the anatomical changes caused by years of medical therapy. ${ }^{111}$

The second barrier to change would be that perhaps fewer investments in time and resources to train ophthalmologists have been allocated in Italy, compared to other countries, where MIGS is already an established part of the treatment paradigm. Of course, every change can generate concerns; in this specific case, we appreciate that: i) switching from medical treatment to new procedural approaches is hard to adopt and even harder to communicate to patients; ii) learning and executing a new procedure is a complex pathway that takes time. These concerns are plausible, but they should not be a barrier to adoption. Published literature on SLT and MIGS confirms that these

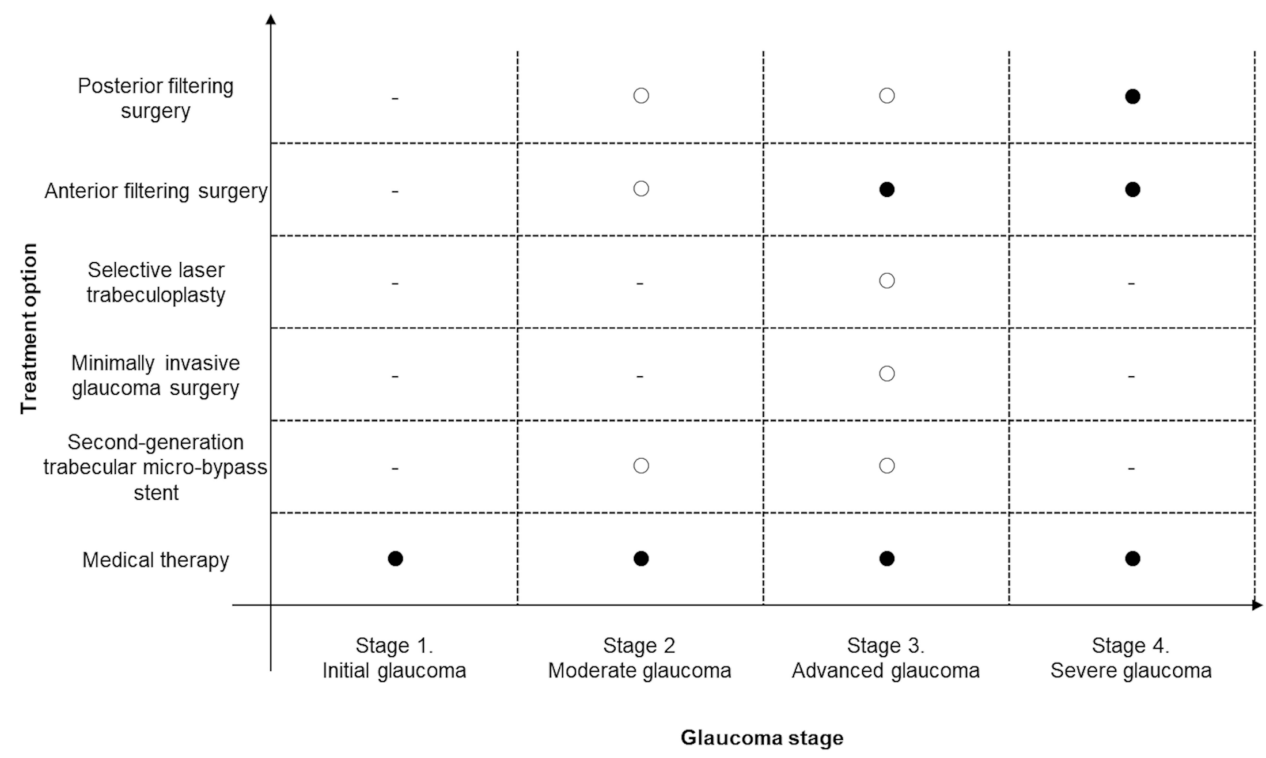

Figure 2 Overview of current glaucoma treatments in Italy*. -no place in therapy; $\circ$ place in therapy for selected patient subgroups; $\bullet$ clear place in therapy. $*$ This figure schematizes the typical trends of glaucoma treatment in Italy, by disease stage. However, this should not be intended as fully representative of the current situation. 
techniques are relatively "easy-to-learn" ${ }^{85,112}$ Evidence on second-generation TBS, for instance, suggests that it is a very direct and predictable procedure, minimally traumatic, with an easy follow-up in both settings, either as a standalone procedure or as a combined procedure with cataract extraction. ${ }^{113}$

Patients take eye drops for a few weeks after surgery, and no weekly controls are necessary as it is required after trabeculectomy because there is no risk of fibrosis and recovery is fast. It is easy to reach the Schlemm's canal and place the stents, and you can immediately see the success of your surgery.

Certainly, physician education and training are crucial for the successful implementation of SLT and MIGS. For instance, plenty of literature emphasizes the importance of guiding laser, minimally invasive, and traditional incisional surgery with gonioscopy. ${ }^{114-116}$ The choice of gonioscopy settings depends on surgery type and is crucial to optimize the procedural success rates. Unfortunately, the members of this panel feel that gonioscopy is not always performed efficiently by many ophthalmologists. Sadly, until these visualization techniques are routinely used in Italy, MIGS will be placed later in the treatment algorithm, inconsistently with its appropriate place in therapy.

The third issue regards the economic sustainability of MIGS for hospitals. Several economic evaluations have demonstrated that MIGS can be cost-effective for healthcare services, compared to other glaucoma management strategies. ${ }^{117-120}$ Furthermore, there is a clear economic rationale to combine cataract extraction and MIGS in one single intervention to save procedural costs. However, Italian hospitals are not receiving adequate remuneration for this combined intervention, to date. As a matter of fact, hospitals obtain a remuneration of up to $€ 1,522$, which is the day-hospital intervention for glaucoma (DH 42 "Interventions on intraocular structures except for retina, iris and crystalline"), ${ }^{121}$ barely covering the acquisition costs of a MIGS device. In other words, with the current remuneration levels, hospitals would not be able to afford overall costs (MIGS device, cataract intraocular lenses, other procedural costs-room, staffing, other equipment, etc.) despite this intervention would be cost-effective for the Italian National Health Service (NHS). This issue is critical for ophthalmologists and is negatively affecting their appetite to learn the new techniques.

\section{Place in Therapy Considerations for Emerging Glaucoma Treatments in Italy}

We tried to schematize our suggested place in therapy of current and emerging glaucoma treatments using the chart showed in Figure 3. Within this concept, identification of the optimal therapy by disease stage is based on the triangulation of: i) likelihood of the treatment to modify ocular surface (thus influencing the choice of future treatments); ii) efficacy of the treatment, intended as the potential to reduce IOP, iii) optimized use of medical therapy, intended as potential to reduce high-doses and/or frequency of combination therapy ( $\geq 2$ drugs to control IOP).

In summary, we believe that a more individualized approach should be adopted when selecting the optimal therapy for early-stage patients while filtering surgery should remain the preferred option in patients with advanced and severe glaucoma, and in selected patients with early-onset and rapidly evolving glaucomatous damage, despite treatment with medical therapy and lessinvasive options.

Within this algorithm, the role of medical therapy would be significantly revised. Pharmacological treatment would be still an option in the early stages of the disease, but only in those situations where IOP control can be achieved with low-dose monotherapy and other situations where other-than medical treatment is contraindicated or is not practically feasible.

In other words, our suggested approach is to flexibly switch to SLT or MIGS options as early as possible, when there is a clear perception that pharmacological treatment will hardly be effective.

It should be specified that where multiple options can lead to a benefit, patients' personal preferences should be considered. Despite the presence of different techniques, there is still a number of patients who would prefer to continue medical therapy. ${ }^{122}$

Medical therapy would remain an important option in the post-filtering surgery setting, in those patients who have not achieved adequate IOP control and do not have any other effective option left.

However, it is important to remark that changes of therapeutic approach must always be related to failure/ lack of disease control, as any therapeutic modification would lead to an increase in the number of visits and additional examinations, with consequent increase of costs. $^{123}$ 


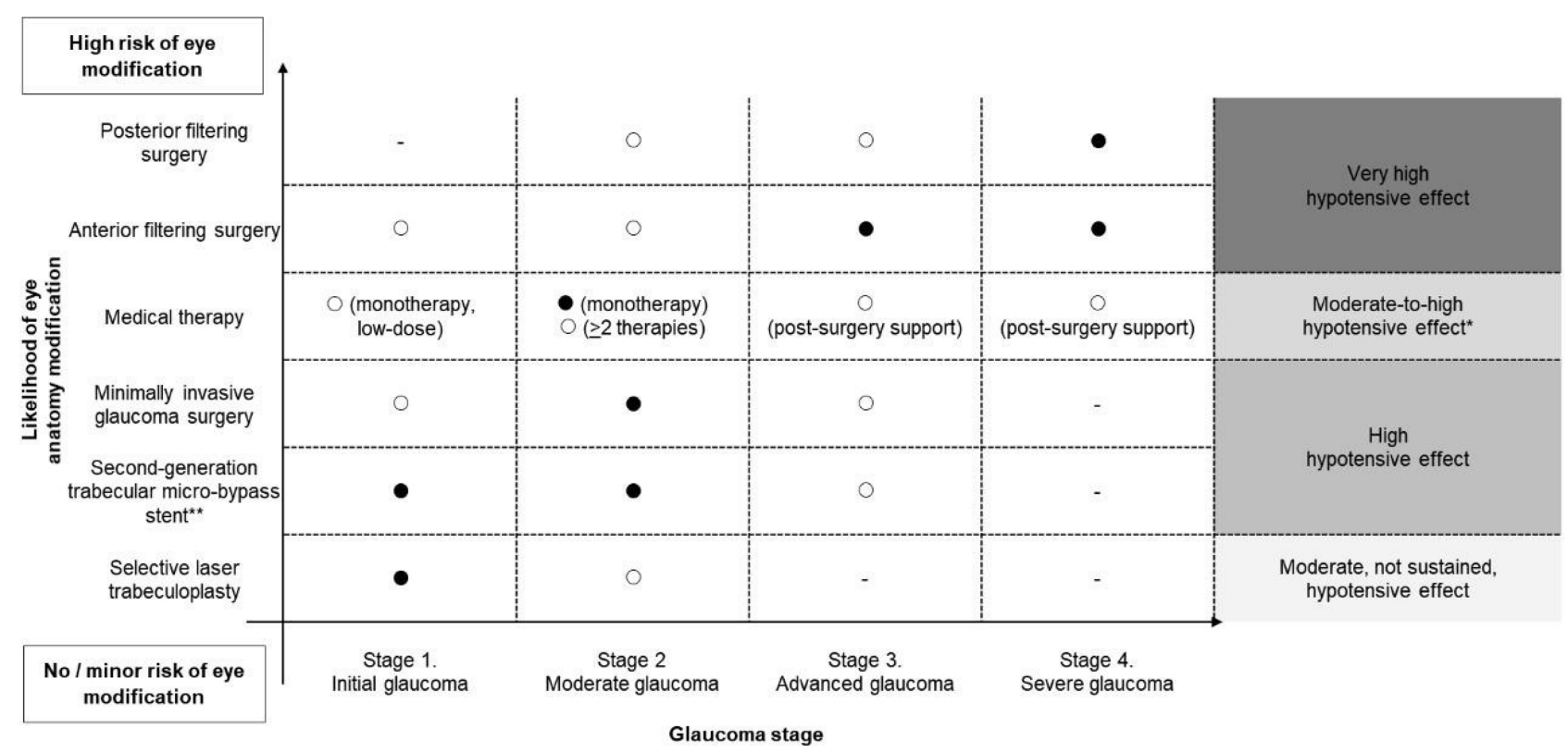

Figure 3 Suggested place in therapy ${ }^{\circ}$ of glaucoma treatments in Italy. -no place in therapy; $\circ$ place in therapy for selected patient subgroups; $\bullet$ clear place in therapy. ${ }^{\circ}$ Place in therapy to be adapted according to available economic resources of the INHS and financial affordability. *Often achieved with combination of medical therapies. ** Given its better level of safety, second-generation trabecular micro-bypass stent has been differentiated from the other MIGS. MIGS, Minimally invasive glaucoma surgery. Abbreviation: INHS, Italian National Health Service.

Back to the early stages of glaucoma, we believe that SLT, and second-generation TBS, would be the best options to consider in initial glaucoma. With the current data, it is hard to set preference between the two techniques. While SLT remains the least invasive surgical approach and has the advantage of being a repeatable procedure, doubts are left about its long-term efficacy. ${ }^{83,124}$ On the other side, second-generation TBS has shown quite robust data on sustained IOP reduction with minimal use of medical therapy and with excellent safety through 2 years. ${ }^{25,125}$ However, a broad utilization in patients with early-stage glaucoma might require a large investment, not sustainable for the Italian SSN (in Italy, the overall glaucoma population amounts to 550 thousand patients).

Given these economic constraints, the most appropriate therapeutic positioning of second-generation TBS in initial glaucoma would be in patients with additional risk factors that could somehow complicate the achievement of optimal and durable IOP.

In this context, patients in need of cataract surgery would be ideal candidates for second-generation TBS implantation. These patients would undergo surgery anyway and could benefit from a simultaneous trabecular micro-bypass implantation, having the effect of controlling IOP without medication in the medium-term time horizon. This "all-in-one" intervention has a strong clinical rationale and is convenient from an economic and legal perspective (hospitals would reduce the number of admissions and patients would be exposed to a single intervention).

In moderate glaucoma cases, SLT would remain an option for patients who are contraindicated, generally unfit, or who are unwilling to undergo surgery, even if minimally invasive. For most of the remaining patients, MIGS (including second-generation TBS) should be the preferred option. The decision on the most suitable technique, among the possible options, would then depend on several factors: ideally, techniques with the lowest level of invasiveness, not precluding filtering surgery in the future, should be preferred. However, the surgeon should also make a decision based on a careful evaluation of procedural complexity, chances of technical success, most suitable anatomical site to treat. Even in these patients, there would be a strong clinical rationale to consider secondgeneration TBS as one of the most valuable options among MIGS devices.

\section{Conclusions}

Minimal invasive surgery can be defined as "a technique that is safe and is associated with lower postoperative patient morbidity compared with a conventional approach for the same operation". ${ }^{126,127}$ Since its origins (first half 
of the $20^{\text {th }}$ century), tremendous technological progresses have been made, and today, a large proportion of surgical procedures in several therapeutic areas (cardiology, oncology, gastroenterology, etc.) are performed by minimizing invasiveness.

As discussed earlier in this paper, minimally invasive surgery of glaucoma has become an important "asset" in ophthalmology as well. If yesterday, physicians were quite "obliged" to choose between medical therapy and traditional filtering surgery, today they can make more customized, personalized decisions optimizing patients' health and quality of life.

In this paper, we aimed to trace a picture of the treatment landscape of glaucoma in Italy, evaluate current use and place in therapy of the newer and innovative glaucoma treatments, and finally give our perspective on the future changes that should be targeted to optimize glaucoma therapy. We concluded that the potential of MIGS is great, but unfortunately the real impact in the Italian clinical setting has been modest so far, and we feel we are missing an important opportunity to offer patients the best available treatments.

There is a strong rationale for wider use of SLT and MIGS, early in the treatment sequence, in patients with mild to moderate disease at high risk of suboptimal IOP control with medical therapy, or in patients who need high-dose combination therapy to adequately lower IOP. In this context, the second-generation TBS seems one of the best examples of the "minimally invasive" concept. This product is safe, straightforward to implant, effective in reducing IOP and use of medication and is a good candidate to become the standard of care in glaucoma patients in need of cataract surgery.

Of course, we understand that any change takes time; on top of that, a mindset change like this must be accompanied by investments in information and training, and improved communication between clinical and surgeon ophthalmologists on patient management. Besides, there are also funding issues to solve, which are making the use of MIGS hardly sustainable by hospitals within the current regulatory and remuneration system. Despite all the issues, though, we strongly believe that this change is in the best interest of patients.

Finally, it is important to acknowledge that this position paper should be considered a "dynamic" document, to be updated on a regular basis with new findings. Importantly, several questions are still open and the newly published studies could answer some outstanding clinical issues. However, new evidence must always be carefully evaluated before accepting new conclusions.

For instance, some doubts on the quality of evidence supporting the use of trabecular micro-bypass devices, like second-generation TBS, have been raised in a recent Cochrane review. ${ }^{128}$ In contrast with most of the currently available studies and technology appraisals, this review concluded that the evidence on second-generation TBS was not robust enough (effectiveness of the intervention has not been clearly demonstrated). However, an in-depth analysis of the review suggests that several issues might have affected the conclusions: i) the review and metaanalyses did not differentiate outcomes between firstand second-generation TBS, which are, de facto, two different technologies; ii) the review has been conducted and published before the publication of the pivotal trial of second-generation TBS, ${ }^{25}$ the most important evidence for this product; iii) the clinical outcome that was primarily investigated in the meta-analysis, ie, proportion of patients who were drop-free, was not the primary endpoint of second-generation TBS trials, which have been designed and sampled upon a more traditional, universally accepted primary endpoint of proportion of patients with $\geq 20 \%$ reduction of unmedicated DIOP. ${ }^{25}$

Also, this conclusion seems to contradict some other important observations: i) the level of published evidence supporting second-generation TBS is robust; ii) more than half a million patients in 40 countries have benefited from trabecular micro-bypass therapies; ${ }^{129}$ iii) important health technology assessment agencies in the US and Europe, in charge of reimbursement recommendations, have made positive recommendations on the use of secondgeneration TBS. ${ }^{130,131}$

Thus, we strongly believe that years of experience in laser technologies and MIGS devices are robust enough to include them in the therapeutic algorithm of glaucoma. Of course, evidence generation is of crucial importance to respond to unanswered questions about comparative evidence among MIGS, or QoL measurement in patients undergoing MIGS. But for now, we believe it is more important to acknowledge that there is a relevant access gap in Italy, and to practically intervene with policies, guidelines, information to make these emerging treatments available to the Italian patients.

\section{Abbreviations}

ACG, angle-closure glaucoma; BCVA, best-corrected visual acuity; CDVA, corrected distance visual acuity; 
DIOP, diurnal intraocular pressure; EGS, European Glaucoma Society; IOP, intraocular pressure; MIGS, minimally invasive glaucoma surgery; NHS, National Health Service; OAG, open-angle glaucoma; OHT, ocular hypertension; POAG, primary open-angle glaucoma; QoL, quality of life; SLT, selective laser trabeculoplasty; TBS, trabecular micro-bypass stent; US, United States.

\section{Disclosure}

Gianluca Furneri reports consulting fees from Glaukos for conducting the analysis for EBMA Consulting SRL. Dr Stefano Gandolfi reports grants and personal fees from Glaukos, during the conduct of the study; grants and personal fees from Ivantis, Novartis, Allergan, AERIE, Santen, Fidia and Dompè, outside the submitted work. Dr Antonio Maria Fea is a consultant for Ivantis, Glaukos, iSTAR, Gore, ELT Sight, Eye D, and reports non-financial support from Allergan, outside the submitted work. The authors report no other conflicts of interest in this work.

\section{References}

1. Biggerstaff KS, Lin A. Glaucoma and quality of life. Int Ophthalmol Clin. 2018;58(3):11-22. doi:10.1097/IIO.0000000000000230

2. Quigley H, Broman AT. The number of people with glaucoma worldwide in 2010 and 2020. Br J Ophthalmol. 2006;90:262-267. doi:10.1136/bjo.2005.081224

3. Società Oftalmologica Italiana (SOI). Glaucoma - L'importanza di una diagnosi precoce.

4. Wang Y, Alnwisi S, Ke M. The impact of mild, moderate, and severe visual field loss in glaucoma on patients' quality of life measured via the Glaucoma Quality of Life-15 Questionnaire. Medicine (Baltimore). 2017;96:48.

5. Ritch R, Schlötzer-Schrehardt U, Konstas AGP. Why is glaucoma associated with exfoliation syndrome? Prog Retin Eye Res. 2003;22:253-275. doi:10.1016/S1350-9462(02)00014-9

6. Hiller R, Sperduto RD, Krueger DE. Pseudoexfoliation, intraocular pressure, and senile lens changes in a population-based survey. Arch Ophthalmol. 1982;100(7):1080-1082. doi:10.1001/archopht.1982.01030040058007

7. Puska P. Lens opacity in unilateral exfoliation syndrome with or without glaucoma. Acta Ophthalmol. 2009;72(3):290-296. doi:10.1111/j.1755-3768.1994.tb02761.x

8. Famà F, Castagna I, Salmeri G. Influence of pseudoexfoliation syndrome on human lens transparency. Ann Ophthalmol. 1993;25 (12):440-441.

9. Buhrmann RR, Quigley HA, Barron Y, West SK, Oliva MS, and Mmbaga BBO. Prevalence of glaucoma in a rural East African population. Investig Ophthalmol Vis Sci. 2000;41 (1):40-48.

10. Rotchford AP, Johnson GJ. Glaucoma in Zulus: a population-based cross-sectional survey in a rural district in South Africa. Arch Ophthalmol. 2002;120(4):471-478. doi:10.1001/archopht.120.4. 471

11. Tielsch JM, Katz J, Sommer A, Quigley HA, Javitt JC. Family history and risk of primary open angle glaucoma: the baltimore eye survey. Arch Ophthalmol. 1994;112(1):69-73. doi:10.1001/ archopht.1994.01090130079022
12. Leske MC, Connell AMS, Schachat AP. The Barbados eye study: prevalence of open angle glaucoma. Arch Ophthalmol. 1994;112 (6):821-829. doi:10.1001/archopht.1994.01090180121046

13. Iwase A, Suzuki Y, Araie M, et al. The prevalence of primary open-angle glaucoma in Japanese: the Tajimi study. Ophthalmology. 2004;111(9):1641-1648. doi:10.1016/j.ophtha.2004.03.029

14. Varma R, Ying-Lai M, Francis BA, et al. Prevalence of open-angle glaucoma and ocular hypertension in Latinos: the Los Angeles Latino eye study. Ophthalmology. 2004;111(8):1439-1448. doi:10.1016/j.ophtha.2004.01.025

15. Dielemans I, Vingerling JR, Wolfs RCW, Hofman A, Grobbee DE, and de Jong PTVM. The prevalence of primary open-angle glaucoma in a population-based study in the Netherlands: the Rotterdam study. Ophthalmology. 1994;101(11):1851-1855. doi:10.1016/S0161-6420(94)31090-6

16. Bonomi L, Marchini G, Marraffa M, et al. Prevalence of glaucoma and intraocular pressure distribution in a defined population: the Egna-Neumarkt study. Ophthalmology. 1998;105(2):209-215. doi:10.1016/S0161-6420(98)92665-3

17. Mitchell P, Smith W, Attebo K, Healey PR. Prevalence of open-angle glaucoma in Australia: the blue mountains eye study. Ophthalmology. 1996;103(10):1661-1669. doi:10.1016/S01616420(96)30449-1

18. Hyman L, Wu SY, Connell AMS, et al. Prevalence and causes of visual impairment in the Barbados Eye Study. Ophthalmology. 2001;108(10):1751-1756. doi:10.1016/S01616420(01)00590-5

19. Shingleton BJ, Pasternack JJ, Hung JW, O’Donoghue MW. Three and five year changes in intraocular pressures after clear corneal phacoemulsification in open angle glaucoma patients, glaucoma suspects, and normal patients. J Glaucoma. 2006;15(6):494-498. doi:10.1097/01.ijg.0000212294.31411.92

20. Samuelson TW, Katz LJ, Wells JM, Duh YJ, Giamporcaro JE. Randomized evaluation of the trabecular micro-bypass stent with phacoemulsification in patients with glaucoma and cataract. Ophthalmology. 2011;118(3):459-467. doi:10.1016/j.ophtha.2010.07.007

21. Arthur SN, Cantor LB, Wudunn D, et al. Efficacy, safety, and survival rates of IOP-lowering effect of phacoemulsification alone or combined with canaloplasty in glaucoma patients. J Glaucoma. 2014;23(5):316-320. doi:10.1097/IJG.0b013e318 $2741 \mathrm{ca} 9$

22. Chen PP, Lin SC, Junk AK, et al. The effect of phacoemulsification on intraocular pressure in glaucoma patients: a report by the american academy of ophthalmology. Ophthalmology. 2015;122 (7):1294-1307. doi:10.1016/j.ophtha.2015.03.021

23. Nguyen DQ, Niyadurupola N, Tapp RJ, O'Connell RA, Coote MA, Crowston JG. Effect of phacoemulsification on trabeculectomy function. Clin Exp Ophthalmol. 2014;42(5):433-439. doi:10.1111/ceo.12254

24. Pillunat LE, Erb C, Jünemann AGM, Kimmich F. Micro-invasive glaucoma surgery (MIGS): a review of surgical procedures using stents. Clin Ophthalmol. 2017;11:1583-1600. doi:10.2147/OPTH.S135316

25. Samuelson TW, Sarkisian SR, Lubeck DM, et al. Prospective, randomized, controlled pivotal trial of an Ab interno implanted trabecular micro-bypass in primary open-angle glaucoma and cataract: two-year results. Ophthalmology. 2019;126(6):811-821. doi:10.1016/j. ophtha.2019.03.006

26. Fea AM, Belda JI, Rekas M, et al. Prospective unmasked randomized evaluation of the iStent inject ${ }^{\circledR}$ versus two ocular hypotensive agents in patients with primary open-angle glaucoma. Clin Ophthalmol. 2014;8:875-882. doi:10.2147/OPTH.S59932

27. Arriola-Villalobos P, Martinez-De-La-Casa JM, Diaz-Valle D, Morales-Fernandez L, Fernandez-Perez C, Garcia-Feijoo J. Glaukos iStent inject ${ }^{\circledR}$ trabecular micro-bypass implantation associated with cataract surgery in patients with coexisting cataract and open-angle glaucoma or ocular hypertension: a long-term study. J Ophthalmol. 2016;2016:1-7. doi:10.1155/2016/1056573 
28. Schargel K, Belda J, and Rial L. Long-Term IOP and medication reduction with second-generation MIGS trabecular micro-bypass stents for OAG patients on one preoperative medication. Poster presented at: EGS 2018. In: 13th EGS Congress 19-22 May, 2018; Florence, Italy.

29. Tseng VL, Yu F, Lum F, Coleman AL. Risk of fractures following cataract surgery in medicare beneficiaries. JAMA. 2012;308 (5):493-501. doi:10.1001/jama.2012.9014

30. Leske MC, Heijl A, Hyman L, Bengtsson B. Early manifest glaucoma trial: design and baseline data. Ophthalmology. 1999;106 (11):2144-2153. doi:10.1016/S0161-6420(99)90497-9

31. Kass MA, et al. The ocular hypertension treatment study: a randomized trial determines that topical ocular hypotensive medication delays or prevents the onset of primary open-angle glaucoma. Arch Ophthalmol. 2002;120(6):701. doi:10.1001/ archopht.120.6.701

32. European Glaucoma Society. Terminology and guidelines for glaucoma: treatment principles and options (Chapter 3). $\mathrm{Br}$ J Ophthalmol. 2017;130-195.

33. Susanna R Jr., Vessani RM. Staging glaucoma patient: why and how? Open Ophthalmol J. 2009;3(2):59-64. doi:10.2174/ 1874364100903010059

34. Gupta V, Srivastava RM, Sihota R, Kaur J, Kumar S, Singh D. Determinants of severity at presentation among young patients with early onset glaucoma. Indian J Ophthalmol. 2013;61(10):546-551. doi:10.4103/0301-4738.121064

35. Bengtsson B, Heijl A. A visual field index for calculation of glaucoma rate of progression. Am $J$ Ophthalmol. 2008;145 (2):343-353. doi:10.1016/j.ajo.2007.09.038

36. Tatham AJ, Weinreb RN, Medeiros FA. Strategies for improving early detection of glaucoma: the combined structure-function index. Clin Ophthalmol. 2014;8:611-621. doi:10.2147/OPTH. S44586

37. Leske MC, Heijl A, Hyman L, Bengtsson B, Dong LM, Yang Z. Predictors of long-term progression in the early manifest glaucoma trial. Ophthalmology. 2007;114(11):1965-1972. doi:10.1016/j. ophtha.2007.03.016

38. Iancu R, Corbu C. Intraocular pressure after phacoemulsification in patients with uncontrolled primary open angle glaucoma. $J$ Med Life. 2014

39. Naveh N, Kottass R, Glovinsky J, Blumenthal M, Bar-Sever D. The long-term effect on intraocular pressure of a procedure combining trabeculectomy and cataract surgery, as compared with trabeculectomy alone. Ophthalmic Surg. 1990.

40. Gaasterland DE, Ederer F, Beck A, et al. The Advanced Glaucoma Intervention Study (AGIS): 7. The relationship between control of intraocular pressure and visual field deterioration. $\mathrm{Am}$ J Ophthalmol. 2000

41. Collaborative Normal-Tension Glaucoma Study Group. The effectiveness of intraocular pressure reduction in the treatment of normal-tension glaucoma. Am J Ophthalmol. 1998;126(4):498-505. doi:10.1016/S0002-9394(98)00272-4

42. Heijl A, Leske MC, Bengtsson B, et al. Reduction of intraocular pressure and glaucoma progression: results from the early manifest glaucoma trial. Arch Ophthalmol. 2002;120(10):1268. doi:10.1001/ archopht.120.10.1268

43. Prum BE, Rosenberg LF, Gedde SJ, et al. Primary open-angle glaucoma preferred practice pattern ${ }^{\circledR}$ guidelines. Ophthalmology. 2016.

44. Nordstrom BL, Friedman DS, Mozaffari E, Quigley HA, Walker AM. Persistence and adherence with topical glaucoma therapy. Am J Ophthalmol. 2005;140(4):598.e1-598.e11. doi:10. 1016/j.ajo.2005.04.051

45. Belhassen M, Laforest L, Licaj I, Van Ganse É. Étude observationnelle sur l'adhésion précoce aux traitements hypotonisants antiglaucomateux. Therapies. 2016;71(5):491-499. doi:10.1016/j. therap.2016.02.033
46. Jaenen N, Baudouin C, Pouliquen P, Manni G, Figueiredo A, Zeyen T. Ocular symptoms and signs with preserved and preservative-free glaucoma medications. Eur $J$ Ophthalmol. 2007;17(3):341-349. doi:10.1177/112067210701700311

47. Pisella PJ, Pouliquen P, Baudouin C. Prevalence of ocular symptoms and signs with preserved and preservative free glaucoma medication. Br J Ophthalmol. 2002;86(4):418-423. doi:10.1136/ bjo.86.4.418

48. Stewart WC, Stewart JA, Nelson LA. Ocular surface disease in patients with ocular hypertension and glaucoma. Curr Eye Res. 2011;36(5):391-398. doi:10.3109/02713683.2011.562340

49. Landers J, Martin K, Sarkies N, Bourne R, Watson P. A twenty-year follow-up study of trabeculectomy: risk factors and outcomes. Ophthalmology. 2012;119(4):694-702. doi:10.1016/j. ophtha.2011.09.043

50. Palanca-Capistrano AM, Hall J, Cantor LB, Morgan L, Hoop J, WuDunn D. Long-term outcomes of intraoperative 5-fluorouracil versus intraoperative Mitomycin C in primary trabeculectomy surgery. Ophthalmology. 2009;116(2):185-190. doi:10.1016/j.ophtha.2008.08.009

51. Reibaldi A, Uva MG, Longo A. Nine-year follow-up of trabeculectomy with or without low-dosage mitomycin-c in primary open-angle glaucoma. Br J Ophthalmol. 2008;92(12):1666-1670. doi:10.1136/bjo.2008.140939

52. Ang GS, Varga Z, Shaarawy T. Postoperative infection in penetrating versus non-penetrating glaucoma surgery. $\mathrm{Br} J$ Ophthalmol. 2010;94(12):1571-1576. doi:10.1136/bjo.2009.163923

53. Mathew RG, Murdoch IE. The silent enemy: a review of cataract in relation to glaucoma and trabeculectomy surgery. Br J Ophthalmol. 2011;95(10):1350-1354. doi:10.1136/bjo.2010.194811

54. Paletta Guedes RA, Paletta Guedes VM, Freitas SM, Chaoubah A. Quality of life of medically versus surgically treated glaucoma patients. J Glaucoma. 2013;22(5):369-373. doi:10.1097/ IJG.0b013e31824ceb8b

55. Cheng JW, Cheng SW, Cai JP, Li Y, Wei RL. Systematic overview of the efficacy of non penetrating glaucoma surgery in the treatment of open angle glaucoma. Med Sci Monit. 2011;17(7):RA155RA163. doi:10.12659/MSM.881840

56. Guedes RAP, Guedes VMP, Chaoubah A. Does phacoemulsification affect the long-term success of non-penetrating deep sclerectomy? Ophthalmic Surg Lasers Imaging. 2010;41 (2):228-235. doi:10.3928/15428877-20100303-12

57. Gilmour DF, Manners TD, Devonport H, Varga Z, Solebo AL, Miles J. Viscocanalostomy versus trabeculectomy for primary open angle glaucoma: 4-year prospective randomized clinical trial. Eye. 2009;23(9):1802-1807. doi:10.1038/sj.eye.6702726

58. Yalvac IS, Sahin M, Eksioglu U, Midillioglu IK, Aslan BS, Duman S. Primary viscocanalostomy versus trabeculectomy for primary open-angle glaucoma: three-year prospective randomized clinical trial. J Cataract Refract Surg. 2004;30(10):2050-2057. doi:10.1016/j.jcrs.2004.02.073

59. Schaefer JL, Levine MA, Martorana G, Koenigsman H, Fran Smith M, Sherwood MB. Failed glaucoma drainage implant: long-term outcomes of a second glaucoma drainage device versus cyclophotocoagulation. Br J Ophthalmol. 2015;99(12):1718-1724. doi:10.1136/bjophthalmol-2015-306725

60. Saheb H, Gedde SJ, Schiffman JC, Feuer WJ. Outcomes of glaucoma reoperations in the tube versus trabeculectomy (TVT) study. Am J Ophthalmol. 2014;157(6):1179-1189.e2. doi:10.1016/j.ajo.2014.02.027

61. Sood S, Beck AD. Cyclophotocoagulation versus sequential tube shunt as a secondary intervention following primary tube shunt failure in pediatric glaucoma. $J$ AAPOS. 2009;13(4):379-383. doi:10.1016/j.jaapos.2009.05.006

62. Rapuano CJ, Schmidt CM, Cohen EJ, et al. Results of alloplastic tube shunt procedures before, during, or after penetrating keratoplasty. Cornea. 1995;14(1):26???32. doi:10.1097/00003226199501000-00005 
63. Chen J, Gedde SJ. New developments in tube shunt surgery. Curr Opin Ophthalmol. 2019 Mar;30(2):125-131. doi: 10.1097/ ICU.0000000000000549.

64. Gedde SJ, Herndon LW, Brandt JD, Budenz DL, Feuer WJ, Schiffman JC. Postoperative complications in the tube versus trabeculectomy (TVT) study during five years of follow-up. Am J Ophthalmol. 2012.

65. Vijaya L, Manish P, Ronnie G, Shantha B. Management of complications in glaucoma surgery. Ind J Ophthalmol. 2011.

66. Stefan C, Batras M, Iliescu Daniela A, Timaru Cristina M, De Simone A, Hosseini-Ramhormozi J. Current options for surgical treatment of glaucoma. Rom J Ophthalmol. 2015;59(3):194-201.

67. Garg A, Gazzard G. Selective laser trabeculoplasty: past, present, and future. Eye. 2017;32:863-876. doi:10.1038/eye.2017.273

68. Koucheki B, Hashemi H. Selective laser trabeculoplasty in the treatment of open-angle glaucoma. $J$ Glaucoma. 2012;21 (1):65-70. doi:10.1097/IJG.0b013e3182027596

69. Ong K, Ong L, Ongz LB. Corneal endothelial abnormalities after selective laser trabeculoplasty (SLT). J Glaucoma. 2015;24 (4):286-290. doi:10.1097/IJG.0b013e3182946381

70. Baser EF, Akbulut D. Significant peripheral anterior synechiae after repeat selectIve laser trabeculoplasty. Can J Ophthalmol. 2015;50 (3):e36-e38. doi:10.1016/j.jcjo.2015.02.006

71. Song J. Complications of selective laser trabeculoplasty: a review. Clin Ophthalmol. 2016;137. doi:10.2147/OPTH.S84996

72. Lee JWY, Chan CWS, Wong MOM, Chan JCH, Li Q, Lai JSM. A randomized control trial to evaluate the effect of adjuvant selective laser trabeculoplasty versus medication alone in primary openangle glaucoma: preliminary results. Clin Ophthalmol. 2014;1987. doi:10.2147/OPTH.S70903

73. McIlraith I, Strasfeld M, Colev G, Hutnik CML. Selective laser trabeculoplasty as initial and adjunctive treatment for open-angle glaucoma. $J$ Glaucoma. 2006;15(2):124-130. doi:10.1097/ 00061198-200604000-00009

74. Nagar M. A randomised, prospective study comparing selective laser trabeculoplasty with latanoprost for the control of intraocular pressure in ocular hypertension and open angle glaucoma. $\mathrm{Br} J$ Ophthalmol. 2005;89(11):1413-1417. doi:10.1136/bjo.2004.052795

75. Mcalinden C. Selective laser trabeculoplasty (SLT) vs other treatment modalities for glaucoma: systematic review. Eye (Basingstoke). 2014.

76. Leahy KE, White AJ. Selective laser trabeculoplasty: current perspectives. Clin Ophthalmol. 2015.

77. Lee JWY, Yau GSK, Yick DWF, Yuen CYF. Micro pulse laser trabeculoplasty for the treatment of open-angle glaucoma. Med (United States). 2015;94(49):1-6.

78. Fea A. Micropulse diode laser trabeculoplasty (MDLT): a Phase II clinical study with 12 months follow-up. Clin Ophthalmol. 2008;2 (2):247. doi:10.2147/OPTH.S2303

79. Gazzard G, Konstantakopoulou E, Garway-Heath D, et al. Selective laser trabeculoplasty versus eye drops for first-line treatment of ocular hypertension and glaucoma (LiGHT): a multicentre randomised controlled trial. Lancet. 2019;393(10180):1505-1516. doi:10.1016/S0140-6736(18)32213-X

80. Nagar M, Luhishi E, Shah N. Intraocular pressure control and fluctuation: the effect of treatment with selective laser trabeculoplasty. Br J Ophthalmol. 2009;93(4):497-501. doi:10. 1136/bjo.2008.148510

81. Wong MOM, Lee JWY, Choy BNK, Chan JCH, Lai JSM. Systematic review and meta-analysis on the efficacy of selective laser trabeculoplasty in open-angle glaucoma. Surv Ophthalmol. 2015;60(1):36-50. doi:10.1016/j.survophthal.2014.06.006

82. Li X, Wang W, Zhang X. Meta-analysis of selective laser trabeculoplasty versus topical medication in the treatment of open-angle glaucoma1. BMC Ophthalmol. 2015;15:1. doi:10.1186/s12886-0150091-2
83. Fea AM, Ahmed IIK, Lavia C, et al. Hydrus microstent compared to selective laser trabeculoplasty in primary open angle glaucoma: one year results. Clin Exp Ophthalmol. 2017;45(2):120-127. doi: $10.1111 /$ ceo. 12805

84. Ansari E. An update on implants for Minimally Invasive Glaucoma Surgery (MIGS). Ophthalmol Ther. 2017;6(2):233-241. doi:10. 1007/s40123-017-0098-2

85. Brandão LM, Grieshaber MC. Update on minimally invasive glaucoma surgery (MIGS) and new implants. $J$ Ophthalmol. 2013;2013:1-12. doi:10.1155/2013/705915

86. Lavia C, Dallorto L, Maule M, Ceccarelli M, Fea AM. Minimallyinvasive glaucoma surgeries (MIGS) for open angle glaucoma: a systematic review and meta-analysis. PLoS One. 2017;12:1-33 p. doi:10.1371/journal.pone. 0183142

87. Saheb H, Ahmed IIK. Micro-invasive glaucoma surgery: current perspectives and future directions. Curr Opin Ophthalmol. 2012;23 (2):96-104. doi:10.1097/ICU.0b013e32834ffle7

88. Fea AM. Phacoemulsification versus phacoemulsification with micro-bypass stent implantation in primary open-angle glaucoma. Randomized double-masked clinical trial. J Cataract Refract Surg. 2010;36(3):407-412. (). doi:10.1016/j.jcrs.2009.10.031

89. Manasses Leon Au DT. The new era of glaucoma micro-stent surgery. Ophthalmol Ther. 2016;5.

90. Costagliola C, Dell'Omo R, Agnifili L, et al. How many aqueous humor outflow pathways are there? Surv Ophthalmol. 2019.

91. Zeppa L, Ambrosone L, Guerra G, Fortunato M, Costagliola C. Using canalography to visualize the in vivo aqueous humor outflow conventional pathway in humans. JAMA Ophthalmol. 2014;132 (11):1281. doi:10.1001/jamaophthalmol.2014.567

92. Arriola-Villalobos P, Martínez-de-la-Casa JM, Díaz-Valle D, et al. Mid-term evaluation of the new Glaukos iStent with phacoemulsification in coexistent open-angle glaucoma or ocular hypertension and cataract. $\mathrm{Br} J$ Ophthalmol. 2013;97(10):1250-1255. doi:10. 1136/bjophthalmol-2012-302394

93. Gonnermann J, Bertelmann E, Pahlitzsch M, Maier-Wenzel AKB, Torun N, Klamann MKJ. Contralateral eye comparison study in MICS \& MIGS: trabectome ${ }^{\circledR}$ vs iStent Inject ${ }^{\circledR}$. Graefe's Arch Clin Exp Ophthalmol. 2017;255(2):359-365. doi:10.1007/s00417-0163514-8

94. Macher T, Häberle H, Wächter J, Thannhäuser C, Aurich H, Pham DT. Trabecular microbypass stents as minimally invasive approach after conventional glaucoma filtration surgery. J Cataract Refract Surg. 2018;44(1):50-55. doi:10.1016/j.jcrs.2017.10.039

95. Hengerer FH, Auffarth GU, Riffel C, Conrad-Hengerer I. Prospective, non-randomized, 36-month study of second-generation trabecular micro-bypass stents with phacoemulsification in eyes with various types of glaucoma. Ophthalmol Ther. 2018;7(2):405-415. doi:10.1007/s40123-018-0152-8

96. Harasymowycz P Single surgeon evaluation of second-generation trabecular micro-bypass stents in patients with mild to severe glaucoma. Annual meeting of the American Society of Cataract and Refractive Surgeons, April 13-17, 2018; Washington, DC.

97. Clements C Audit of australian outcomes with iStent inject combined with cataract surgery. Annual Meeting of the Asia-Pacific Glaucoma Congress, April 13-15, 2018; Busan, Korea.

98. Voskanyan L, García-Feijoó J, Belda JI, Fea A, Jünemann A, Baudouin C. Prospective, unmasked evaluation of the iStent ${ }^{\circledR}$ Inject system for open-angle glaucoma: synergy trial. Adv Ther. 2014;31(2):189-201. doi:10.1007/s12325-014-0095-y

99. Poley BJ, Lindstrom RL, Samuelson TW, and Schulze R. Intraocular pressure reduction after phacoemulsification with intraocular lens implantation in glaucomatous and nonglaucomatous eyes. Evaluation of a causal relationship between the natural lens and open-angle glaucoma. J Cart Refract Surg. 2009;35 (11):1946-1955. doi:10.1016/j.jcrs.2009.05.061 
100. Berdahl J, Voskanyan L, Myers JS, et al. Implantation of two second-generation trabecular micro-bypass stents and topical travoprost in open-angle glaucoma not controlled on two preoperative medications: 18-month follow-up. Clin Experiment Ophthalmol. 2017;45(8):797-802. doi:10.1111/ceo.12958

101. Singh RB, Ichhpujani P, Thakur S, Jindal S. Promising therapeutic drug delivery systems for glaucoma: a comprehensive review. Ther Adv Ophthalmol. 2020;12:251584142090574.

102. Lavik E, Kuehn MH, Kwon YH. Novel drug delivery systems for glaucoma. Eye Nature Publishing Group. 2011;25:578-586.

103. Allergan. Prescribing information Durysta. Available from: https:// media.allergan.com/products/durysta_pi.pdf. Accessed August 8, 2020.

104. Medeiros FA, Walters TR, Kolko M, et al. Phase 3, randomized, 20-month study of bimatoprost implant in open-angle glaucoma and ocular hypertension (ARTEMIS 1). Ophthalmology. 2020. doi:10.1016/j.ophtha.2020.06.018

105. Società Oftalmologica Italiana (SOI). Storia della Società. Available from: https://www.sedesoi.com/storia.php. Accessed August 8, 2020.

106. Resnikoff S, Lansingh VC, Washburn L, et al. Estimated number of ophthalmologists worldwide (International Council of Ophthalmology update): will we meet the needs? $\mathrm{Br}$ $J$ Ophthalmol. 2020;104(4):588-592. doi:10.1136/bjophthalmol2019-314336

107. Lindén C, Heijl A, Jóhannesson G, Aspberg J, Andersson Geimer S, Bengtsson B. Initial intraocular pressure reduction by mono- versus multi-therapy in patients with open-angle glaucoma: results from the Glaucoma Intensive Treatment Study. Acta Ophthalmol. 2018;96(6):567-572. doi:10.1111/ aos. 13790

108. Noecker RJ, Herrygers LA, Anwaruddin R. Corneal and conjunctival changes caused by commonly used glaucoma medications. Cornea. 2004;23(5):490-496. doi:10.1097/01.ico.0000116526. 57227.82

109. Broadway DC, Grierson I, O'brien C, Hitchings RA. Adverse effects of topical antiglaucoma medication: II The outcome of filtration surgery . Arch Ophthalmol. 1994;112(11):1446-1454. doi:10.1001/archopht.1994.01090230060021

110. Aydin Kurna S, Acikgoz S, Altun A, Ozbay N, Sengor T, Olcaysu OO. The effects of topical antiglaucoma drugs as monotherapy on the ocular surface: a prospective study. J Ophthalmol. 2014;2014.

111. Lemij HG, Hoevenaars JGMM, Van Der Windt C, et al. Patient satisfaction with glaucoma therapy: reality or myth? Clin Ophthalmol. 2015;9:783-784. doi:10.2147/OPTH.S83197

112. Latina MA, De Leon JMS. Selective laser trabeculoplasty. Ophthalmol Clin North Am. 2005;18(3):409-419. doi:10.1016/j. ohc.2005.05.005

113. Kent C. Glaucoma: in search of the perfect stent. Rev Ophtalmol. 2015.

114. Shareef S. Gonioscopy is essential for MIGS. Glaucoma Today. 2016.

115. Alward WLM, Longmuir RA. Gonioscopic laser surgery. Color Atlas Gonioscopy. 2017.

116. Grover DS, Godfrey DG, Smith O, Feuer WJ, Montes De Oca I, Fellman RL. Gonioscopy-assisted transluminal trabeculotomy, Ab interno trabeculotomy: technique report and preliminary results. Ophthalmology. 2014;121(4):855-861. doi:10.1016/j. ophtha.2013.11.001

117. Ahmed I, Goeree R, Patel V, Murray J, Falvey H, Podbielski DW. A Canadian cost-utility analysis of two trabecular micro-bypass stents implanted at time of cataract surgery in patients with mild-tomoderate open-angle glaucoma. Value Heal. 2018;21:S261. doi:10.1016/j.jval.2018.09.1558
118. Patel V, Ahmed I, Podbielski D, Falvey H, Murray J, Goeree R. Cost-effectiveness analysis of standalone trabecular micro-bypass stents in patients with mild-to-moderate open-angle glaucoma in Canada. $J$ Med Econ. 2019;22(4):390-401. doi:10.1080/ 13696998.2019.1572013

119. Berdahl JP, Khatana AK, Katz LJ, et al. Cost-comparison of two trabecular micro-bypass stents versus selective laser trabeculoplasty or medications only for intraocular pressure control for patients with open-angle glaucoma. J Med Econ. 2017;20(7):760-766. doi:10.1080/13696998.2017.1327439

120. Iordanous Y, Kent JS, Hutnik CML, Malvankar-Mehta MS. Projected cost comparison of trabectome, istent, and endoscopic cyclophotocoagulation versus glaucoma medication in the ontario health insurance plan. $J$ Glaucoma. 2014;23(2):e112-e118. doi:10.1097/IJG.0b013e31829d9bc7

121. Italian Ministry of Health, Inpatient intervention tariffs. Italian Republic Official Gazette N. 23. 28 Jan 2013; Attachment 1.

122. IOVS. Glaucoma treatments, patient perspectives and preferences. ARVO J. 2020.

123. Costagliola C, Parmeggiani F, Sebastiani A. Assessing the costeffectiveness of switching from a $\beta$-blocker to latanoprost in the treatment of ocular hypertension. Expert Opin Pharmacother. 2003;4(10):1775-1788. doi:10.1517/14656566.4.10.1775

124. Khouri AS, Lari HB, Berezina TL, Maltzman B, Fechtner MDRD. Long term efficacy of repeat selective laser trabeculoplasty. J Ophthalmic Vis Res. 2014;9(4):444. doi:10.4103/2008-322X.150814

125. Fea AM, Consolandi G, Zola M, et al. Micro-bypass implantation for primary open-angle glaucoma combined with phacoemulsification: 4-year follow-up. J Ophthalmol. 2015;2015:1-4. doi:10.1155/ 2015/795357

126. Hamad GG, Curet M. Minimally invasive surgery. Am J Surg. 2010;199(2):263-265. doi:10.1016/j.amjsurg.2009.05.008

127. McCrory B, LaGrange CA, Hallbeck MS. Quality and safety of minimally invasive surgery: past, present, and future. Biomed Eng Comput Biol. 2014;6:BECB.S10967. doi:10.4137/BECB.S10967

128. Le JT, Bicket AK, Wang L, Li T. Ab interno trabecular bypass surgery with iStent for open-angle glaucoma. Cochrane Database Syst Rev. 2019. doi:10.1002/14651858.CD012743.pub2

129. Glaukos. Glaukos milestone achievements. Available: https://www. glaukos.com/about-us/glaukos-history/. Accessed August 8, 2020.

130. Haute Autorité de Santé (HAS). Avis De La CNEDiMTS. iSTENT INJECT; 2018.

131. National Institute for Health and Care Excellence (NICE). Interventional procedure overview of trabecular stent bypass microsurgery for open-angle glaucoma. 2017.

132. Lindstrom R, Lewis R, Hornbeak DM, et al. Outcomes following implantation of two second-generation trabecular micro-bypass stents in patients with open-angle glaucoma on one medication: 18-month follow-up. $A d v$ Ther. 2016;33(11):2082-2090. doi:10.1007/s12325-016-0420-8

133. Hengerer FH, Auffarth GU, Riffel C, Conrad-Hengerer I. Secondgeneration trabecular micro-bypass stents as standalone treatment for glaucoma: a 36-month prospective study. Adv Ther. 2019;36 (7):1606-1617. doi:10.1007/s12325-019-00984-9

134. Clement CI, Howes F, Ioannidis AS, Shiu M, Manning D. One-year outcomes following implantation of second-generation trabecular micro-bypass stents in conjunction with cataract surgery for various types of glaucoma or ocular hypertension: multicenter, multi-surgeon study. Clin Ophthalmol. 2019;13:491-499. doi:10.2147/OPTH. S187272

135. Fechtner RD, Voskanyan L, Vold SD, et al. Five-year, prospective, randomized, multi-surgeon trial of two trabecular bypass stents versus prostaglandin for newly diagnosed open-angle glaucoma. Ophthalmol Glaucoma. 2019;2(3):156-166. doi:10.1016/j.ogla. 2019.03.004 


\section{Publish your work in this journal}

Clinical Ophthalmology is an international, peer-reviewed journal covering all subspecialties within ophthalmology. Key topics include: Optometry; Visual science; Pharmacology and drug therapy in eye diseases; Basic Sciences; Primary and Secondary eye care; Patient Safety and Quality of Care Improvements. This journal is indexed on PubMed
Central and CAS, and is the official journal of The Society of Clinical Ophthalmology (SCO). The manuscript management system is completely online and includes a very quick and fair peer-review system, which is all easy to use. Visit http://www.dovepress.com/ testimonials.php to read real quotes from published authors. 